\title{
PERFORMANCE-BASED BUdGETING AS SURVEILlANCE FOR THE ACCOUNTABILITY OF LOCAL GOVERNMENTS
}

\author{
Mujennah
}

Department Of Accountancy

Sekolah Tinggi Ilmu Ekonomi Indonesia

Banjarmasin

\section{Budi Artinah}

Department Of Accountancy

Sekolah Tinggi Ilmu Ekonomi Indonesia

Banjarmasin

\section{Safriansyah}

Department Of Accountancy

Sekolah Tinggi Ilmu Ekonomi Indonesia

Banjarmasin

*Corrosponding author's Email: $\underline{\text { mujennah@stiei-kayutangi-bjm-ac.id }}$

Peer-review under responsibility of $3^{\text {rd }}$ Asia International Multidisciplanry Conference 2019 editorial board (http://www.utm.my/asia/our-team/) (C) 2019 Published by Readers Insight Publisher, lat 306 Savoy Residencia, Block 3 F11/1,44000 Islamabad. Pakistan, info@ readersinsight.net This is an open access article under the CC BY-NC-ND license (http://creativecommons.org/licenses/by-nc-nd/4.0/). 


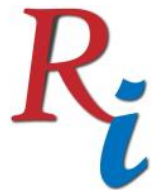

Asia Proceedings of Social Sciences

(APSS)

www.readersinsight.net/APSS

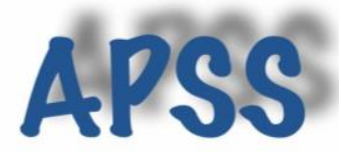

\section{Re search $\mathrm{H}$ igh I igh t s}

Performance accountability of local government presents budget allocation and realization to carry out the main tasks in achieving performance indicators. The achievement of these performance indicators can be accounted for and realized through performance-based budgeting (Young, 2003). However, in the implementation of performance-based budgeting required surveillance, control, responsibility, and accountability of the performance of government agencies (SOX 2002, Iman (2005). Internal control system helps to conduct surveillance against the course of governance and financial management are clean and responsible (IIA Standards, 2002). The purpose of this research is to find out whether performance-based Budgets and the Internal Control System effect on performance accountability of local government. The study proposed nine hypothesis and The results showed that the implementation of the budget, the budget reporting, control and monitoring activities (supervision) has an influence on performance accountability of government agencies. Budget planning, performance evaluation, control environment, risk assessment, information and communication has no effect on. performance accountability of local government

Keywords: Performance Based Budgeting, Internal Control System, Accountability, Local Governments

\section{Research Objectives}

Based on the background and the problem has been addressed before, then the purpose of this research is:

1. To explain the effect of Budget Planning (X1) on Performance Accountability of local goverments

2. To explain the effect of Budget Implementation $\left(\mathrm{X}_{2}\right)$ on Performance Accountability of local goverments

3. To explain the effect of Budget Reporting $\left(\mathrm{X}_{3}\right)$ on Performance Accountability of local goverments

4 To explain the effect of Budget Evaluation $\left(\mathrm{X}_{4}\right)$ on Performance Accountability of gocal goverments

5. To explain the effect of the Control Environment $\left(\mathrm{X}_{5}\right)$ on Performance Accountability of local goverments

6. To explain the effect of Risk Assessment $\left(\mathrm{X}_{6}\right)$ on Performance Accountability of local goverments

7. To explain the effect of Control Activities $\left(\mathrm{X}_{7}\right)$ on Performance Accountability of local goverments

8. To explain the effect of Information and Communication $\left(\mathrm{X}_{8}\right)$ on Performance Accountability of local goverments

9. To explain the effect of Supervision ( $\left.\mathrm{X}_{9}\right)$ on Performance Accountability of local goverments

\section{Methodology}

The methods used in the design of this research is the multiple regression analysis with quantitative methods. The population used in this study is all Local Government civil servants in Banjarbaru City Inspectorates. Namely 65 civil servants and 39 samples will be 


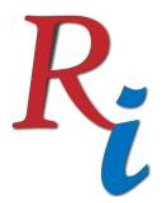

\section{Asia Proceedings of Social Sciences \\ (APSS) \\ www.readersinsight.net/APSS}

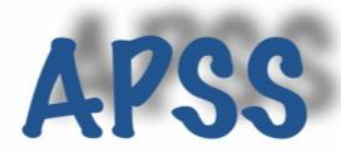

taken. The sampling technique used for performance-based budget variables and public accountability is purposive sampling. Validity of the test used to measure the validity of a questionnaire. Testing the validity of data-collecting instruments in this research using SPSS program 24.0 help for windows. The validity of the testing done by doing the bilvariate correlation between each score indicator with a total score of invalid constructs. Bilvariate correlation analysis results by looking at the output of the Pearson Correlation (Ghozali, 2015). The criteria if the value of the sig (2-tailed) on a total score of invalid constructs < 0.05 item questions or statements said invalid. Multiple linear regression aims to determine the functional relationship between independent variables together on the dependent variable.

\section{Results}

The value of $r$ table with $n=39$ at significance of $5 \%$, it is found that the value of $r$ table is 0.308 indicating that all item statements in the research instrument used have numbers calculated $\mathrm{r}$ values greater than $\mathrm{r}$ table. This means that all statement items are valid. The instrument reliability testing in this study used the Cronbach's Alpha technique. Reliability assessment criteria is if the reliability coefficient results are at least 0.6 , the research instrument is reliable (Sugiyono, 2014: 220). The following is a recapitulation of the results of the instrument reliability. showed that all variables in the research instrument used had Cronbach's Alpha numbers above 0.6. Multiple Regression equations obtained from the influence of the variables $\left(X_{1}\right)$ budget planning, implementation of the budget $\left(X_{3}\right)$, the reporting of budget $\left(\mathrm{X}_{4}\right)$, performance evaluation $\left(\mathrm{X}_{6}\right)$, environmental Control $\left(\mathrm{X}_{5}\right)$, risk assessment $\left(\mathrm{X}_{6}\right)$, control activities $\left(\mathrm{X}_{7}\right)$, Information and communication $\left(\mathrm{X}_{8}\right)$, and monitoring $\left(\mathrm{X}_{10}\right)$ on the performance accountability of government agencies $(\mathrm{Y})$ is as follows.

$Y=30,318+0,599 X_{1}+(-4,738) X_{2}+3,254 X_{3}+1,167 X_{4}+(-0,179) X_{5}+(-0,115) X_{6}+(1,294) X_{7}+(-$ $0,211) X_{8}+(-0,426) X_{9}$

\section{Findings}

The test results show that Based on the results of multiple regression. In this study the zero hypothesis (H0) and an alternative hypothesis (Ha) stated as follows: Ho: $b \leq 0$, performancebased budget and the application of the system of internal controls has no effect against the positive performance accountability of local government agencies. Ha: $b>0$, performancebased budget and the application of the system of internal control positive effect against the regional government agency performance accountability. Based on the results of hypothesis testing using multiple regression test, can be obtained at the following conclusions. Budget Planning, The control environment, Risk Assessment, Performance evaluation, Information and communication have no significant effect performance accountability of Local Governments and Budget implementation, Budget reporting, Control activities, Monitoring has a significant effect on the performance accountability of Local Governments.

\section{References}

COSO, (2013) Internal Control - Integrated Framework. Defining Issues. No. (13-26),U.S

Ghozali, Imam, (2015). "Aplikasi Analisis Multivariate Dengan Program SPSS, Edisi Keempat”. Semarang:Universitas Diponegoro.

Halidayati, Ira. (2014). Pengaruh Pengawasan Internal, Pengawasan Eksternal dan Implementasi Anggaran Berbasis Kinerja Terhadap Kinerja Pemerintah 


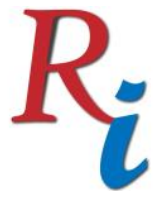

\section{Asia Proceedings of Social Sciences}

(APSS)

www.readersinsight.net/APSS

Daerah.Padang; Universitas Negeri Padang

Iman Sjahputra Tunggal, dan Amin Widjaja Tunggal. 2005, "Memahami Sarbanes-Oxley Act (SOX 2002)", Harvarindo Jakarta.

Indra Bastian. (2006).“Akuntansi Sektor Publik: Suatu Pengantar”. Jakarta: Erlangga

Kaltsum, Ummu dkk (2013). "Pengaruh Kejelasan Sasaran Anggaran Terhadap Akuntabilitas Kinerja Instansi Pemerintah Melalui Sistem Pengendalian Intern sebagai Variabel Intervening". Semarang; Universitas Diponegoro

LAN dan Badan Pengawas Keuangan dan Pembangunan, (2000). "Pedoman Penyusunan Pelaporan Akuntabilitas Kinerja Instansi Pemerintah". Jakarta: Lembaga Administrasi Negara dan BBK.

Sugiyono. (2014). Metode Penelitian Bisnis. Bandung: Alfabeta.

The Institute of Internal Auditor. (2002). System Auditability and Control, Modul 2 Audit and Control Environment.

Young, R.D. (2003)." Performance-Based Budget System". USC: Institute for Public Service and Policy Research. 